\title{
Manuela COUTINHO, Economia Social em Portugal. A emergência do terceiro sector na politica social, Lisboa, CPIHTS e APSS, 2003, 311 p.
}

Manuela Coutinho licenciou-se em Serviço Social em 1980, pelo Instituto Superior de Serviço Social do Porto, mantendo um percurso académico, no domínio da Economia e da Política Social. Doutorou-se em Economia, em 2002, pelo Instituto de Economia e Gestão da Universidade Técnica de Lisboa, tendo, consequentemente, resultado a presente obra. $\mathrm{O}$ seu percurso profissional, bastante dinâmico, abrange a actividade de docente e de Assistente Social com exercício de funções em IPSS's e na Segurança Social. O seu livro reflecte este mesmo percurso que concilia o desenvolvimento académico com a prática profissional direccionada para os problemas sociais como a pobreza e a exclusão social, no âmbito do terceiro sector.

A pobreza e a exclusão social são dois conceitos concomitantes, sobrepostos, complementares e que persistem no tempo, desde o passado e a julgar pelos difíceis avanços, infelizmente no futuro. Em torno da história a sua conceptualização tem sido largamente analisada, uma vez que estes conceitos são efémeros na sua significação temporal e apresentam características diversas nas várias partes do mundo. Pela sua diversidade e complexidade, o grande desafio centra-se nas estratégias de intervenção que só podem prosseguir eficazmente se se adaptarem às exigências e necessidades de cada realidade. Os actores desta intervenção são vários e têm-se posicionado neste combate à exclusão social de forma combinada com os seus próprios objectivos e interesses. Podemos integrar estes actores em três sectores da economia comummente utilizados: o primeiro sector ou sector privado, que baseia a sua actuação no lucro e na satisfação das necessidades privadas, o segundo sector ou sector público que assenta a sua actuação em objectivos de política e programas governamentais e o terceiro sector (constituído por diferentes 
instituições organizadas sob a forma de associação, fundação, misericórdia, cooperativa, mutualidade, clube, etc.), emergente da sociedade civil e que integra as organizações, não mercantis, sem fins lucrativos e informais, baseia-se em objectivos sociais.

A par da incapacidade do mercado de financiar os serviços necessários e fundamentais e a par da crise do Estado de Providência, o terceiro sector tem recebido crescente atenção por parte dos investigadores e conforme justifica a autora no seu livro, a criação de alternativas económicas tendentes à resolução dos problemas sociais que afectam a sociedade de hoje, torna a reflexão em torno do terceiro sector uma questão necessária e oportuna (p.1). Assim, Coutinho definiu como objectivo principal do seu trabalho a análise do papel das organizações do terceiro sector, enquanto dimensão constitutiva da Política Social na sua relação com a Economia. Para atingir este objectivo a autora desenvolveu o seu estudo através de uma abordagem holística e recorreu a procedimentos metodológicos que cruzam a análise quantitativa com a qualitativa.

O livro está organizado em 3 partes fundamentais, apresentando 5 capítulos.

Após a introdução considerada o capítulo 1, o capítulo 2, denominado por Problematização teórica em torno do eixo terceiro sector e política social na sua relação com a economia, comporta uma análise histórica, teórica e contextualizante do terceiro sector na Política Social, desde a Revolução Industrial até à sociedade actual. Com função bastante esclarecedora são definidas duas regras para a Política Social, devendo estas, ser o âmago da sua actuação: a política social deve ser capaz de vitalizar e maximizar o potencial produtivo da população, como o investimento em recursos humanos, capacidades e auto-suficiência; e deve ser capaz de minimizar as necessidades da população em matéria de subsídios de Estado e de dependência relativamente a eles (p. 42). Concomitante com este desafio, a autora explora e analisa o conceito de Economia Social, como um novo rumo para a Política Social, que concilia objectivos económicos e sociais num vector de acção comum e sobretudo que co-responsabiliza os agentes sociais da sociedade civil em detrimento do papel privilegiado do sector público. O terceiro sector surge como resposta integradora da nova economia social, orientada para a competitividade (papel regulador do mercado), a solidariedade (procura de soluções para pessoas em situação de exclusão social) e a sustentabilidade (ir ao encontro das gerações presentes sem comprometer as gerações futuras). Ainda no segundo capítulo, apresenta uma breve abordagem aos conceitos de pobreza e exclusão social e alguns princípios metodológicos para promover iniciativas económicas assentes numa 
cultura de solidariedade e respeitadoras da singularidade dos problemas que afectam os indivíduos.

O capítulo 3, Emergência do Terceiro Sector em Portugal e na Europa, apresenta a evolução do terceiro sector no plano nacional e internacional. É feita uma abordagem à história da protecção social em Portugal desde os seguros sociais obrigatórios, na Primeira República, a transição para o sistema unificado de Segurança Social, até às iniciativas reformadoras da década de 90 . Seguindo-se uma revisão do panorama europeu tendo em consideração seis países que a autora considerou de referência, uma vez que reforçam os fenómenos de organização da sociedade civil, para o desempenho de actividades económicas, com objectivo de desenvolvimento social.

O capítulo 4, Sociedade Civil: um instrumento de análise sobre a influência do terceiro sector na política social, dedica-se à apresentação do estudo de caso realizado com duas organizações de Viana do Castelo, a ARVAL (Artesãos Reunidos do Vale do Lima) - organização cooperativa, com base na reciprocidade, em que o carácter económico é assumido como muito importante, embora em complementaridade com os objectivos sociais e a ACEP (Associação Cultural e de Educação Popular) - organização em que o objectivo dominante é de natureza social e a dimensão económica reduz-se à prestação de serviços, o seu financiamento resulta do capital social e de outras fontes. Apesar desta diferença, os eixos de análise foram os mesmos e são: o enquadramento geral da organização $e$ as actividades desenvolvidas $e$ os seus determinantes, estratégias de inserção pelo económico. A análise a estes eixos permitiu à autora três conclusões: estas associações foram criadas para responder a diferentes grupos sociais que não encontravam solução para os seus problemas nas instituições existentes, foram criadas a partir da mobilização de indivíduos e grupos que assumiram a responsabilidade de resolver os problemas de forma colectiva e voluntária e mobilizaram à sua volta as capacidades de que necessitavam e operaram sinergias de base local, por último, a riqueza cultural de que se investiram desde $o$ início produziu um contínuo de sinergias importantes para a assimilação e continuidade das suas iniciativas (p.263).

Por último, o capítulo 5 é dedicado à conclusão da obra. Coutinho resume 5 elementos característicos do terceiro sector: o ser pró-activo, a forma como assume a diversidade de direitos e de responsabilidades, a capacidade de realizar objectivos de auto-ajuda, de ajuda mútua e de solidariedade assentes em actividades económicas, a capacidade para promover os recursos locais e utilizá-los para satisfazer as necessidades do colectivo, a procura de um equilibrio, entre objectivos sociais e necessidades de sobrevivência, economicamente sustentado (p.274). O 
terceiro sector é um ponto essencial de criação de alternativas aos sistemas tradicionais de política social e de economia social.

O grande desafio da nova economia social será a criação de iniciativas económicas que mobilizem o desenvolvimento do capital social, para que a política social vitalize e maximize o potencial produtivo da população e ponha em evidência solidariedade e não meros rendimentos, sem contrapartida (p.287).

Esta obra pauta-se por ser de reflexão, a autora oferece-nos uma revisão de conceitos fundamentais para a discussão do tema de forma esclarecedora, mas por outro lado, exerce alguma influência no sentido de sensibilizar o leitor a não encerrar os seus conhecimentos nesta obra. $\mathrm{O}$ conselho não é directo, mas está implícito na forma como divulgou o seu trabalho, coberto de questões e reflexões. O rigor está presente nas abordagens históricas e teóricas sobre o tema que combinam na perfeição com o lado empírico do estudo, dotado de grande seriedade e sentido de adequação e aproveitamento do contexto prático em benefício do contexto teórico.

Joana Guerra 